\title{
PENDIDIKAN ISLAM DALAM PERSPEKTIF FILSAFAT ILMU
}

\author{
Mohammad Muslih
}

ISID Gontor Ponorogo Jawa TImur

E-mail: muhd.muslih@gmail.com

\begin{abstract}
Abstrak: Proses dan hasil keilmuan sangat ditentukan oleh landasan filosofisnya, yang meliputi kerangka teori, paradigma keilmuan dan asumsi dasar. Ketiga hal ini menjadi basis filosofis yang berfungsi memberikan kerangka, arahan serta corak keilmuan yang dihasilkan. Islamic worldview dalam perspektif filsafat ilmu, pada dasarnya merupakan asusmsi teologismetafisis atau hard core dalam keilmuan pendidikan Islam. Inilah yang menjadi ciri khas yang membedakannya dengan pendidikan sekuler. Asumsi teologis-metafisis tersebut dapat diidentikkan dengan problem al-Sawabit (yang mapan), sedangkan paradigma dan teori dapat diidentikkan dengan al-mutah\}awwil (yang berubah). Dengan paradigma seperti ini, pendidikan Islam akan mampu mengidentifikasi perbedaan antara pendekatan dakwah dengan pendekatan ilmiah.
\end{abstract}

Abstract: The process and the scintifc result will depend on their philosophical bases, covering theoretical framework, scientifc paradigm and basic assumption. The three bases become the philosophical base that function to allot framework, direction and scientific colour that will be produced. The Islamic wordview in the perspective of the philospy of science basically serves as the theological-methaphisical assumntion or hard core in the scientifc field of the Islamic eduation. It is the special characteristic that makes it different from the secular education. Employing this kind of paradigm, the Islamic education will be able to identify the difference between proselytazing approach from scientific approach.

Kata Kunci: pendidikan Islam, filsafat ilmu, teologis metafisis, paradigma 


\section{PENDAHULUAN}

Dalam dunia pendidikan, kajian seputar kaitan antara problem keilmuan dengan proses pendidikan tampaknya masih merupakan wilayah yang diterlantarkan. Kondisi masyarakat umumnya yang cenderung praktis dan pragmatis tampaknya telah membawa dunia pendidikan melupakan aspek terpenting itu. Padahal pandangan tentang apa hakikat ilmu dan bagaimana pertumbuhannya menjadi salah satu pilar yang sangat menentukan untuk memahami apa hakikat pendidikan, yang pada gilirannya juga menentukan corak dan pelaksanaan pendidikan itu sendiri. Dan kenyataannya, pendidikan memang merupakan aktivitas keilmuan juga.

Dalam perspektif Filsafat Ilmu, persoalan keilmuan yang paling sentral hingga saat ini adalah persoalan hakikat ilmu dan pertumbuhan ilmu pengetahuan. Kaitannya dengan pendidikan, persoalan yang berkembang kemudian adalah bagaimana konsekuensi bangunan keilmuan dengan dunia pendidikan. Kalau proses pendidikan berarti memajukan dan mengembangkan pengetahuan manusia, bagaimana sebaiknya proses itu dilakukan? Sebagai aktivitas keilmuan, pendidikan sudah pasti berangkat dari pemahaman tentang hakikat ilmu dan kerangka pengembangannya. Maka sudah menjadi keniscayaan bagi dunia pendidikan untuk memasuki diskursus filsafat keilmuan. Bagaimanakah dunia pendidikan jika dilihat dalam perpektif Filsafat llmu. Inilah pokok pembicaraan dalam tulisan ini.

\section{PENDIDIKAN DAN PROBLEM DEMARKASI}

Dalam kajian Filsafat Ilmu, problem demarkasi dipopulerkan oleh Karl R. Popper pada awal abad ke-20. Popper adalah seorang Filsuf Ilmu asal Wina Austria yang awalnya bergabung dalam kelompok Vienna Circle yang mengembangkan Positivime Logis, namun akhirnya berbalik menjadi filsuf yang paling lantang 
mengkritik pendapat kelompok tersebut. ${ }^{1}$ Inti gagasan Popper ini adalah menemukan garis pemisah antara ilmu dan yang bukan ilmu, antara yang ilmiah dengan yang tidak ilmiah, dengan memberikan kriteria secara ketat terhadap apa yang disebut dengan ilmu (science) itu. ${ }^{2}$ Jika melihat maksud demarkasi ini, sebenarnya bisa juga dikatakan bahwa ia merupakan isu tertua dari filsafat keilmuan, karena sepanjang sejarahnya, refleksi kefilsafatan memang selalu dalam kerangka kebenaran pengetahuan dengan merontokkan "godaan" apa saja yang mengurangi tingkat kebenaran pengetahuan. Tampaknya pokok pembicaraan filsafat semacam ini terus berlangsung hingga hari ini, maka bisa jadi "demarkasi" menjadi persoalan keilmuan sepanjang masa (perennial problem).

Kaitannya dengan dunia pendidikan, persoalan filsafat keilmuan yang muncul kemudian adalah, apakah pendidikan benar-benar merupakan aktivitas keilmuan yang juga berperan mengembangkan ilmu, paling tidak, di kalangan [maha]siswanya. Atau, benarkah pendidikan merupakan satu sistem yang berbasiskan ilmu pengetahuan?

Jika dirunut dari awal perkembangan filsafat, pembicaraan tentang hakikat hidup, hakikat realitas, dan hakikat pengetahuan oleh para filsuf klasik, seperti Socrates, Plato, dan Aristoteles, sejarah mencatat, merupakan awal tumbuh kembangnya satu "spieses" pengetahuan filsafat yang membedakan diri dengan "pengetahuan" mitologi yang telah lebih dulu mewabah pada masyarakat manusia. Garis pembedanya, jika yang disebut pertama dapat dijelaskan proses penemuannya, sedangkan yang disebut kedua umumnya berkembang dari generasi ke generasi

${ }^{1}$ K. Bertens, Filsafat Barat Abad XX: Inggris-Jerman (Jakarta: Gramedia, 1983), h. 74-75; lihat juga A, MacIntyre, "Popper, Karl Raimund," dalam The Encyclopedia of Philosophy, Edited by Paul Edwards (New York: The Macmillan Company and The Free Press, 1967), h. 398.

${ }^{2}$ Alfons Taryadi, Epistemologi Pemecahan Masalah Menurut Karl Popper (Jakarta: PT Gramedia Pustaka Utama, 1991), h. 49. 
pada tradisi tertentu, sehingga hanya diterima saja tanpa ada penjelasan yang cukup. Pada tahap ini, problem demarkasi bisa juga dimaknai sebagai genderang perang melawan mitos yang dimengerti tidak memenuhi kriteria pengetahuan yang benar.

"Penjelasan" yang cukup terhadap proses penemuan pengetahuan (untuk ini Popper menyebutnya dengan logic of scientific discovery) tampaknya merupakan kata kunci dari kriteria ilmiah yang paling dasar. Disebut demikian, karena pembicaraan ini sudah dimulai oleh para filsuf Yunani generasi awal sebagaimana disebut di atas. Socrates dan Plato misalnya mengajukan proses "transendensi" untuk menggapai idealisme atau pengetahuan hakiki. ${ }^{3}$ Sedangkan Aristoteles menjelaskannya dengan proses "abstraksi" dan "definisi" untuk membangun "konsep" yang benar sebelum dibuat suatu "proposisi", dan dari proposisi lalu dibuat "silogisme". Proses demikian ini menjadi jalan bagi manusia untuk membangun pengetahuan yang benar, yang oleh Aristoteles disebut dengan hylemorphy, ${ }^{4}$ yaitu menyatunya antara form dan matter, antara hukum pikir dengan isi pemikiran. Konsep-konsep kunci dari Aristoteles ini menjadi pembahasan menarik dalam Ilmu Logika ('ilm manțiq), suatu ilmu yang membicarakan satu model berpikir yang menjadi basis bagi terbangunnya pengetahuan yang benar. ${ }^{5}$ Maka kata "penjelasan" berarti juga logis atau rasional, karena memang hanya yang logis yang bisa dijelaskan, dan sebaliknya tak akan ada penjelasan untuk hal-hal yang tidak logis.

"Aroma" demarkasi juga tercium oleh para filsuf Muslim generasi awal, tak terkecuali juga oleh para mutakallimun (teolog

\footnotetext{
${ }^{3}$ Verhaak, "Plato: Menggapai Dunia Idea", dalam Sutrisno F.X Mudji dan F. Budi Hardiman, Para Filsuf Penentu Gerak Zaman (Yogyakarta: Kanisius, 1994).

${ }^{4}$ Abdullah Sidik, Islam dan Filsafat (Jakarta: Triputra Masa, 1984), h. 9091

${ }^{5}$ Abed al-Jabiri, Binyah al-'Aql al-'Arabī (cet. Ke-8; Beirut: Markaz Dirāsah al-Wahdah al-'Arabiyyah, , 2004), h. 13, $251 \& 383$.
} 
muslim), dan tentu saja juga oleh para teolog Barat di Abad Pertengahan. Maka wajar jika tawaran Aristoteles menjadi sangat mudah diterima, bahkan kemudian menjadi satu mode pemikiran tersendiri yang terkenal dengan masysya'i (peripatetik) yang diidentikkan dengan pemikiran Aristoteles. Beberapa filsuf Muslim seperti al-Kindi, ${ }^{6}$ al-Farabi, ${ }^{7}$ Ibn Sina, ${ }^{8}$ al-Ghazali, ${ }^{9}$ dan Ibn

${ }^{6}$ Dalam bidang Filsafat, karangan al-Kindi pernah diterbitkan oleh Prof. Abu Ridah (1950) dengan judul Rasāil al-Kindi al-Falāsifah (Makalah-makalah filsafat al-Kindi) yang berisi 29 makalah. Prof. Ahmad Fuad Al-Ahwani pernah menerbitkan makalah al-Kindi tentang filsafat pertamanya dengan judul Kitāb al-Kindi ilā al-Mu'tașim bi Allāh fĩ al-Falsafah al-Ūlā (Surat al-Kindi kepada Mu'tashim Billah tentang filsafat pertama). Karangan-karangan al-Kindi mengenai filsafat menunjukkan ketelitian dan kecermatannya dalam memberikan batsasan-batasan makna istilah-istilah yang digunakan dalam terminologi ilmu filsafat. Ilmu-ilmu filsafat yang ia bahas mencakup epistemologi, metafisika, etika dan sebagainya. Sebagaimana halnya para penganut Phytagoras, al-Kindi juga mengatakan bahwa dengan matematika orang tidak bisa berfilsafat dengan baik.

${ }^{7} \mathrm{Di}$ antara karya al-Farabi adalah Kitab Ihsā’ al-'Ulūm. Dengan karyanya itu, dia digelari Guru Kedua. Lihat Osman Bakar, Hierarki Ilmu Membangun Rangka Pikir Islamisasi Ilmu (Bandung: Mizan,1997), h. 47. Edisi bahasa Indonesianya sebagian sudah diterjemahkan oleh Nurcholish Madjid. Lihat Nurcholish Madjid, Khazanah Intelektual Nurcholish Islam (Jakarta: Bulan Bintang,1984), h. 121-133. Dalam bahasa Latin disebut De Scientiis yang diakui sebagai klasifikasi pertama yang dikenal luas oleh kaum Muslimin. Dengan judul: el-Farabi de divisione philosophiae, karya ini tersimpan dalam Oxford Catalog. Mss. Angl. Tom. I. Pars I. h.81 No. 1677; h.140 No. 2590; h. 285 No. 6341; Pars II., h. 50 No. 1553. Lihat Syamsuddin Arif, 'Transmigrasi Ilmu': Dari Dunia Islam ke Eropa, dalam Tsaqafah, Jurnal Peradaban Islam, Vol. 6, No. 2, (Oktober 2010)

${ }^{8}$ Di antara karya Ibnu Sina dalam bidang filsafat adalah kitab al-Syifä'. Al-Syifā̄' ditulis dalam 18 jilid yang membahas ilmu filsafat, mantiq, matematika, ilmu alam dan ilahiyyat. Mantiq al-Syifā's saat ini dikenal sebagai buku yang paling otentik dalam ilmu mantiq islami, sementara pembahasan ilmu alam dan ilahiyyat dari kitab al-Syifa' sampai saat ini juga masih menjadi bahan telaah.

${ }^{9}$ Karya al-Ghazālī al-Mustașfā min 'Ilm al-Ușūl (Kairo:Maktabah alAmiriyyah, 1904), yang kemudian disunting oleh Dr. Muhammad Sulayman alAsyqār, al-Mustașfā (Beirut: Mu'assasah al-Risalah, 1997) merupakan sebuah karya yang mensintesiskan antara Mantik dengan pembahasan 'Ilm Usūl alFiqh. Beberapa kajian menunjukkan bahwa dalam kitab itu al-Ghazālī 
Rusyd, ${ }^{10}$ tidak hanya berjasa mengembangkan ilmu manthiq di dunia Islam, tetapi juga menjadikannya sebagai basis filosofis untuk pengembangan keilmuan yang mereka bangun. Tidak jauh berbeda dengan apa yang terjadi pada para filsuf Yunani di atas, karya-karya para filsuf Muslim yang sarat manthiq ini juga kemudian menjadi semacam pencerahan di tengah-tengah tradisi nujum dan kahn yang menjadi spirit dari karya syair dan karyakarya mitologi lainnya. Demikian juga bagi para mutakallimun, manthiq kecuali digunakan untuk membangun argumen dan keilmuan juga menghindari kesesatan berpikir dalam menghadapi "lawan" debatnya. Hal yang kurang lebih sama juga terjadi pada para teolog Barat. Intinya, penjelasan logis terhadap proses penemuan, menjadi garis pemisah antara ilmu dan yang bukan ilmu, yang kala itu didominasi oleh mitos.

Kaitannya dengan dunia pendidikan adalah soal proses pengetahuan manusia. Menurut logika ini pengetahuan yang benar dapat dicari (mațlüb), ${ }^{11}$ meski tentang sesuatu yang tidak/belum tercerap (al-syai' al-gha'ib; absent thing). Caranya adalah dengan melakukan proses definisi, dalam arti essensialis (hadd; essentialist definition). Singkat kata, sesuatu itu dapat

bermaksud menunjukkan bahwa mantik merupakan mukaddimah bagi ilmuilmu yang lain.

${ }^{10}$ Herny Corbin memberikan testimoni bahwa Ibn Rusyd adalah "the most eminent representative of what has been called Arab philosophy", yakni representasi paling unggul dari filsafat Arab. Lihat Henry Corbin, History of Islamic Philosophy (London and New York: Kegan Paul International, 1962), h. 242. Dalam salah satu karyanya, Ibn Rusyd menegaskan bahwa kebenaran dapat dipetik dimana-mana; kebenaran terdapat dalam Islam dan filsafat Yunani. Di antara pernyataannya: "Kebenaran-kebenaran itu tidak saling bertentangan tetapi saling menguatkan satu sama lain". "Kita harus memungut metodologi dari para pendahulu meskipun berasal dari penganut agama lain". "Kita wajib membaca buku-buku filosof pendahulu. Jika ada kebenaran maka kita terima. Jika ada kesalahan maka kita tolak". Lihat Ibn Rusyd, Faṣl al-Maqāl fī Taqrīr mā Bayn al-Syarīah wa al-Hikmah min al-Ittiṣāl, tahqīq Abid al-Jabiri (Libanon: Markaz Dirāsah al-Wahdah al-'Arabiyyah, 2007), h. 91 \& 96.

${ }^{11}$ Hossein Ziai, Knowledge and Illumination: A Study of Suhrawardi's Hikmat al-Isyraq (Georgia, Brown University, 1990), h. 136. 
diketahui dengan cara mendefinisikannya dengan benar (maka ada kita kenal syarat-syarat definisi yang benar). Inilah proses "tahu" menurut filsafat Peripatetik. Pengaruhnya dalam proses pendidikan, kemudian dapat ditemukan praksis pendidikan yang disibukkan soal definisi dari konsep-konsep yang begitu menyita banyak waktu. Padahal pengetahuan model manthīqi ternyata hanya sampai pada idrāk (persepsi), belum 'ilm, apalagi 'irfān.

Lahirnya Renaisance pada abad ke-16 adalah akhir dari abad Pertengahan sekaligus menandai lahirnya masyarakat modern dengan Rene Descartes sebagai juru bicaranya. Sejak itu, hasil kreatifitas alam pikir Abad Pertengahan diruntuhkan satu persatu. Semua makna dunia objektif tradisional dipertanyakan dan disangsikan secara metodis, sehingga Descartes sampai pada suatu kesimpulan: cogito ergo sum (aku berpikir maka aku ada). Penyangsian secara radikal untuk mencapai kesadaran murni nan sejati inilah hakikat pengetahuan yang digagas Descartes. ${ }^{12}$ Maka kabar apapun dan dari manapun termasuk dari tradisi, budaya, dan agama, jika tidak lolos dari ujian "penyangsian" akan ditolak, sebaliknya jika dapat lolos dari ujian rasional ini akan diterima sebagai kebenaran.

Apa yang ditemukan Descartes pada taraf epistemologis ini adalah peranan mutlak subjek dalam membentuk realitas. Maka dalam sejarah epistemologi, filsuf ini telah membawa isu pengetahuan dari wilayah objek ke subjek. Subjeklah yang membangun dan menciptakan realitas yang diketahui, sehingga menjadi ada. Penekanan pada sisi subjek ini berkembang terus dalam filsafat rasionalis Prancis dan Jerman, dari Descartes melewati Leibniz sampai pada Kant di satu pihak, tetapi juga dalam tradisi Anglo-Saxon yang epistemologinya lebih

\footnotetext{
${ }^{12}$ Dengan metode kesangsian (le doute methodique), menurut Descartes, akan ditemukan yaitu kebenaran dan kepastian yang tak tergoyahkan karena saya mengertinya secara jelas dan terpilah-pilah (claire et distincte, clearly and distinctly). Lihat Bernard Williams, "Rene Descartes", dalam Paul Edwards (Ed.), The Encylopaedia of Philosophy, Volume I and II, (1992), h. 345.
} 
berorientasi psikologis, seperti tampak dalam filsafat Hobbes, Locke, Berkeley, dan Hume di lain pihak. Adalah jasa Immanuel Kant yang bukan hanya meradikalkan penekanan Descartes atas subjek, melainkan juga memperlihatkan the conditions of possibility dari pikiran manusia. Seperti kita ketahui, konsepsi Kant tentang proses pengetahuan manusia adalah suatu proses sintesa antara apa yang ia sebut dengan apriori dan aposteriori. Yang pertama merupakan aktivitas rasio yang aktif dan dinamis dalam membangun dan berfungsi sebagai bentuk (form) pengetahuan, yang terdiri dari kategori-kategori, ${ }^{13}$ sedang yang kedua merupakan cerapan pengalaman yang berfungsi sebagai 'isi' (matter) pengetahuan, yang terdiri dari fenomena objek. Dengan begitu, bagi Kant, pengetahuan, hakikatnya adalah konstruksi apriori manusia. Sebagai konsekuensi cepatnya rasio manusia dalam mengkonstruk pengetahuan, maka Kant menyimpulkan, tidak mungkin pengetahuan manusia menjangkau noumena atau das ding an sich (kenyataan pada dirinya). ${ }^{14}$

Singkat kata, di tangan Descares, Hume hingga Kant ini ilmu pengetahuan dibawa kepada problem epistemologis, yaitu kerangka berpikir ilmuwan dan batas-batasnya sehingga mampu melahirkan pengetahuan yang benar. Persoalannya kemudian, bagaimana konstruksi epistemologi pendidikan yang dikembangkan, atau setidaknya, apakah yang perlu disiapkan terutama terkait mental, rasional, dan spiritualitas dari para

${ }^{13}$ Menurut Kant ada dua belas kategori di dalam akal budi. Kategorikategori yang bersifat asasi adalah kategori yang menunjukkan kuantitas (kesatuan, kejamakan, keutuhan); kualitas (realitas, negasi, dan pembatasan); relasi (substansi dan aksidensi, sebab-akibat [kausalitas], interaksi); modalitas (mungkin-mustahil, ada-tiada, keperluan-kebetulan). Lihat Immanuel Kant, Critique of Pure Reason, Translated by JMD. Meiklejohn (New York: Prometheus Books, 1990), h. 61.

${ }^{14}$ Untuk lebih mamahami konsepsi Kant ini, lihat pembahasan "Kritisisme Kant" dalam buku penulis, Muslih, Filsafat Ilmu; Kajian atas Asumsi Dasar, Paradigma, dan Teori Dasar Ilmu Pengetahuan (Yogyakarta: Belukar Budaya, 2005). 
pelaku pendidikan (guru, murid "pencari ilmu", manajer, leader, dll). Sekalipun isu epistemologi ini sudah tidak begitu populer pada ilmu pengetahuan kontemporer, namun tetap membuat pendidikan sebagai aktivitas keilmuan, tidak bisa dipahami dan tidak bisa dijalankan secara sederhana, apalagi tanpa pertimbangan-pertimbangan epistemologis semacam ini.

Setelah isu epistemologi, tampaknya "logika induksi" yang ditawarkan Francis Bacon di satu sisi ${ }^{15}$ dan "metodologi ilmiah" yang ditawarkan August Comte di sisi yang lain, bisa dikatakan sebagai upaya untuk membangun norma-norma ilmiah dalam kegiatan keilmuan. Menurut Bacon, dalam menjalankan aktifitas ilmiah, para saintis mesti menghindari empat godaan yang oleh Bacon disebut dengan "idola", yaitu idola tribus, idola specus, idola fori, dan idola teatri. ${ }^{16}$ Semenara Comte yang lebih berfokus pada sosiologi memusatkan perhatiannya pada pengetahuan indrawi. Kata 'positif' atau positivisme adalah simbol dari norma dimaksud. Pengetahuan manusia hendaknya tidak melampaui fakta objektif, karena peran subjek tidak lebih dari sekedar instrumen untuk menyalin fakta objektif tersebut. Dalam

\footnotetext{
${ }^{15}$ Dengan logika induksi, Fr. Bacon mengkritik logika deduksi Aristotelian sebagai tidak mengantarkan memperoleh pengetahuan yang baru. Untuk maksud itu Bacon menulis Novum Organun sebagai tandingan Organon Aristoteles.

${ }^{16}$ Menurut Bacon terdapat empat macam idola: pertama adalah Idols of the Tribe (=Bangsa), adalah semacam prasangka yang dihasilkan tanpa pertimbangan yang matang sebagaimana terjadi pada kebanyakan orang awam (tribus), sehingga menjadi semacam prasangka kolektif. Kedua, Prasangka Individual atau Idols of the Cave. Yang dimaksudkan di sini adalah pengalaman-pengalaman dan minat-minat pribadi kita sendiri mengarahkan cara kita melihat dunia, sehingga dunia objektif dikaburkan. Ketiga: Idola Fora (Forum=Pasar) atau Idols of the Marketplace adalah idola yang paling berbahaya. Yang diacu di sini adalah pendapat atau kata-kata orang yang diterima begitu saja sehingga mengarahkan keyakinan-keyakinan dan penilaian-penilaian kita yang tak teruji. Keempat: Idola Theatra (=panggung) atau idols of the theatre. Dengan konsep ini, Bacon mmeperlihatkan sistemsistem filsafat tradisional adalah kenyataan subjektif para filsufnya. Sistemsistem ini dipentaskan, lalu tamat, seperti sebuah teater.
} 
positivisme, pendulum epistemologis bergerak ke pihak objek lagi, namun objek dimaksud bukanlah objek spekulatif sebagaimana tampil dalam Abad Pertengahan, tetapi objek indrawi. Isu utama yang dibawa positivisme adalah problem metodologi. Karenanya, objek dalam positivisme masih dipersempit dengan standar metodologi. Dengan kata lain, 'pengetahuan' dapat dikatakan ilmiah jika menggunakan fakta positif dan yang digali dengan metodologi ilmiah. ${ }^{17}$ Di sini terlihat, bahwa problem demarkasi mengalami pergeseran dari persoalan epistemologi ke persoalan metodologi.

Sampai hari ini metodologi menjadi persoalan penting dalam dunia ilmiah. Ini artinya, gagasan August Comte itu cukup kuat, karenanya masih bertahan sebagai standar ilmiah. Hal ini tidak bisa dilepaskan dari jasa kelompok Lingkaran Wina (Vienna Circle), yang dengan sangat gigih, mendukung pandangan positivisme. Sudah tentu fakta positif dan metodologi ilmiah, mereka setujui sebagai standar ilmiah, namun mereka menambahkan satu lagi, yaitu bahasa ilmiah berupa "proposisi" sebagai standar berikutnya. Untuk itu mereka membedakan pernyataan "yang bermakna" (meaningful) dan "yang tak bermakna" (meaningless). Hanya pernyataan yang meaningful yang ilmiah, sedang yang meaningless sudah tentu tidak ilmiah. Mereka menawarkan prinsip "verifikasi" sebagai garis pemisah antara proposisi yang meaningful dengan yang meaningless. Hanya proposisi yang dikeluarkan oleh sains, yaitu mengenai data-data yang dapat diobservasi, yang dapat dimasukkan ke dalam wilayah yang "bermakna". Sementara semua pernyataan yang tidak dapat dibuktikan kebenarannya secara empiris berdasarkan "asas verifikasi", dimasukkan ke dalam wilayah nonsense. Termasuk ke dalamnya adalah estetika ("lukisan itu indah"), moral ("perbuatan itu tak adil"), dan metafisika ("tuhan

\footnotetext{
${ }^{17}$ Uraian lebih luas lihat Muslih, Filsafat Ilmu...
} 
itu mahakuasa"). Dengan tesis ini, Lingkaran Wina menyingkirkan pencarian makna dalam agama sebagai non-sense.

Beberapa prinsip ini memberikan andil besar bagi tereliminasinya sistem pengetahuan lain dan sistem kebenaran lain yang berada di luar jangkauan standar ilmiah itu, seperti metafisika, seni, tradisi dan lebih-lebih agama. Konsekuensinya, jika ingin disebut ilmiah, maka metafisika, seni, tradisi dan termasuk agama harus mengikuti patok-patok ilmiah secara rigid sebagaimana sains. Di sini derajat sains memang menjadi lebih tinggi dari segalanya. Maka pendidikan Islam sebagai pendidikan yang berbasis Islam, akan sangat sulit memasuki diskursusnya, atau paling tidak perjuangan penuh liku harus terlebih dulu dilaluinya.

Dalam karya Logic of Scientific Discovery, Karl R. Popper masuk dalam diskusi "demarkasi" itu untuk "menyelamatkan" posisi agama dalam pencarian makna atau setidaknya, baik agama maupun sains beroperasi dalam wilayah berbeda dalam pencarian makna. Menurut Popper, garis pemisah antara pernyataan yang bermakna dan yang tidak bermakna sebagai kriteria ilmiah itu sebagaimana Lingkaran Wina itu tidak bisa diterima. Ia pun membuat demarkasi baru dengan kriteria "asas falsifikasi", yaitu demarkasi antara teritorium ilmiah dan non-ilmiah. ${ }^{18}$ Semua pernyataan yang dapat difalsifikasi adalah ilmiah, sementara yang tak dapat difalsifikasi adalah non-ilmiah. Di sini Popper "mengembalikan" posisi agama sebagai pengetahuan yang sahih dalam pencarian makna, karena menurutnya pernyataanpernyataan yang tak bisa difalsifikasi memang tidak ilmiah dan bukan termasuk dalam wilayah sains, tetapi pernyataan itu bukan berarti tidak bermakna.

Di sini, Popper membedakan antara yang ilmiah dengan yang bermakna. Memang peryataan etika, estetika, metafisika,

${ }^{18}$ Karl R. Popper, Logic of Scientific Discovery (New York: Harper and Row, Harper Torchbooks, 1965). 
dan agama itu tidak ilmiah, tetapi bukan berati tidak bermakna. Karena kriteria ilmiah, bagi Popper sudah jelas, yaitu criticable, testable, dan falsifiable. Maka bangunan keilmuan apapun, termasuk Sains Islam adalah sains biasa, temuan ilmuwan [muslim] yang sarat kritik, ujian, dan kesalahan. Untuk itu, Popper memaknai teori cukup sebagai hipotesa, yaitu kesimpulan sementara yang harus terus menerus diuji tingkat kebenarannya.

Beberapa kriteria ilmiah sebagaimana ditawarkan oleh positivisme Comte, positivisme logis Vienna Circle, dan Falsifikasi Popper telah membuat sains dianggap sebagai sistem pengetahuan yang paling objektif karena tak tercampuri nilai subjektifitas apapun. Kondisi ini menarik Thomas S. Kuhn untuk melakukan pembongkaran terhadap sisi-sisi historisitas sains. Dalam penelusurannya terhadap sejarah sains, Kuhn melihat, di balik teori dan metodologi yang berperan pada wilayah logika itu ternyata ada paradigma. Paradigma ilmiah adalah pola pikir kolektif komunitas ilmiah (scientific community) yang menjadi basis tumbuh kembangnya teori dan metodologi. Paradigma memang pola pikir atau pemikiran, tetapi berbeda dengan form atau hukum-hukum pikir sebagaimana logika Aristetotelian, juga berbeda dengan apriori Cartesian dan Categori Kantian yang mengandaikan objektivisme dan universalisme pemikiran, berbeda pula dengan teori dan metodologi positivistik yang bercorak saintisme, paradigma merupakan pemikiran yang terbentuk secara kolektif, sehingga bersifat historis, sosiologis dan antropologis. Dalam pengertian yang lebih spekulatif, paradigma Kuhnian dapat diidentikkan dengan konsep episteme Michel Foucault. ${ }^{19}$ Sedang dalam pengertian yang lebih luas,

\footnotetext{
${ }^{19}$ Episteme merupakan keseluruhan ruang makna dan prapengandaian yang mendasari kehidupan yang memungkinkan pengetahuan bisa terlahir. Maka episteme berisi hal-hal yang bisa dipikirkan dan dipahami pada suatu masa. Michel Foucault lebih jauh melihat, episteme merupakan 'medan' penelusuran epistemologis dari kelahiran pengetahuan. Lihat Michel Foucault, The Order of Think: An Archeology of Human Sciences (New York: Vintage Books, 1994), h. xxii.
} 
paradigma bisa disamakan dengan konsep 'aql mukawwan Abid al-Jabiri, yang tidak saja menjadi basis tumbuhkembangnya ilmu, tetapi juga menjadi basis tumbuhkembangnya tradisi, budaya, dan peradaban, bahkan menentukan perjalanan sejarah. ${ }^{20}$

Paradigma memang kontribusi paling penting dari Kuhn pada dunia keilmuan. Dengan paradigma ini, Kuhn tercatat telah berhasil membawa sains ke wilayah sejarah. Sebagai produk komunitas ilmiah, keberadaan paradigma tidak hanya ditentukan oleh ketepatannya dalam menyelesaikan teka-teki ilmiah (sientific puzzle) tetapi juga menjadi sangat tergantung dengan "kesetiaan" para ilmuwan dalam memegangi nilai bersama. Sama seperti dunia politik dan praktik-praktik manusiawi lainnya, sains juga kontingen terhadap sejarah dan komunitas ilmuwan sehingga kebenaran makna ilmiah pun bisa berubah secara revolusioner seperti dalam politik.

Pada wilayah paradigma ini, historisitas sains menjadi terbukti, karena memang ada beberapa faktor lain di luar keilmuan yang menjadi bagian tak terpisahkan dalam bangunan keilmuan, seperti faktor ekonomi, politik, budaya, bahkan ideologi. Maka semakin membuka jalan bagi masuknya berbagai nilai dalam bangunan keilmuan sains, termasuk nilai etisreligious sebagaimana dicita-citakan pendidikan Islam.

Kaitannya dengan dunia pendidikan, paradigma Kuhnian ini menyadarkan bahwa tidak benar jika semua aktivitas pendidikan itu disamakan saja (atau dianggap sama) sekalipun sama-sama berbasis logika, teori dan thariqah tertentu, karena buktinya masing-masing tradisi (termasuk tradisi keagamaan dari organisasi keagamaan) mengusung paradigma (pola pikir)nya sendiri-sendiri. Maka wajar jika terdapat perbedaan dalam model pendidikan, seperti model pendidikan salaf, model pendidikan modern, model pendidikan Ma'arif, model pendidikan

${ }^{20}$ Abed al-Jabiri, Takwīn al-'Aql al-'Arabī (cet. ke-8; Beirut: Markaz Dirāsah al-Wahdah al-'Arabiyyah, 2002), hh. 5-6 \& 13-16. 
Muhammadiyah, model pendidikan al-Khairat, model pendidikan Gontor, dll. Lahirnya model pendidikan ini sudah tentu terkait pemahaman keislaman sekaligus terkait pemahaman tentang hakikat ilmu.

\section{PENDIDIKAN DAN PROBLEM “GROWTH OF KNOWLEDGE”}

Seperti telah diuraikan di atas, bahwa Thomas Kuhn telah membawa sains ke wilayah sejarah. Untuk itu Kuhn melihat pentingnya Fisafat Ilmu berguru pada sejarah ilmu, sebagai upaya menelusuri proses pembentukan paradigmanya, ${ }^{21}$ sekaligus mengetahui perkembangannya. Dari sinilah "growth of knowledge"22 kemudian menjadi isu penting dari Filsafat Ilmu, yang intinya membicarakan, bagaimana sains bisa dikatakan berkembang. Jawaban dari pertanyaan ini kemudian menjadi asumsi bagi pengembangan sains. Artinya, pandangan terhadap perkembangan sains ini, akan sangat menentukan upaya pengembangannya. Para penganut positivistik melihat bahwa ilmu berkembang jika suatu teori dapat terbukti. Jika ditemukan banyak bukti, maka teori semakin kuat, pada saat itulah ilmu mengalami perkembangan. Perkembangan ilmu sangat tergantung dengan proses akumulasi bukti. Maka sudah bisa dibayangkan, bahwa tugas ilmuwan dalam pengembangan sains pada umumnya adalah menggali dan menemukan bukti sebanyakbayaknya dengan berlandaskan pada teori tertentu. Untuk itu, kebenaran teori kemudian menjadi faktor dominan bagi kebenaran sains, bahkan teori menjadi penentu bagi jalannya proses pembuktian. Untuk menghindari kesalahan, umumnya pilih-pilih fakta yang mendukung teori tampaknya sudah menjadi rahasia umum.

\footnotetext{
${ }^{21}$ Dalam diskursus pemikiran Islam kontemporer, proses pembentukan paradigma ini identik dengan konsep takwin (takwīn al-aql) sebagimana dipopulerkan oleh Muhammad Abed al-Jabiri.

${ }^{22}$ Isu ini kemudian menjadi sangat populer di tangan Imre Lakatos. Lihat Lakatos, Musgrave (Eds.), Criticism and the Growth of Knowledge (Cambridge: Cambridge University Press, 1970).
} 
Dengan proses seperti itu, kaitannya dengan dunia pendidikan, tampaknya tidak jauh berbeda dengan pandangan konvensional (untuk tidak mengatakan tradisional) yang menyatakan, agar dapat tumbuh dan berkembang, pengetahuan manusia harus dipupuk dengan berbagai informasi atau pengetahuan baru. Sudah tentu pandangan seperti ini berangkat dari asumsi bahwa pengetahuan manusia itu benar atau pasti benar, sehingga hadirnya informasi baru itu memperkuat kebenaran pengetahuan yang dimiliki. Maka pemilahan dan pemilihan terhadap informasi dan pengetahuan baru itu menjadi persoalan penting, terutama untuk mendukung pengetahuan terdahulu (ma'lumat sabiqah). Sebagai konsekuensinya, jika ditemukan informasi yang berbeda maka sudah tentu akan dipandang dan diadili sebagai salah. Dengan begitu, pendidikan berarti suatu proses tiada henti untuk menambah pengetahuan dan informasi baru. Karena memang pengetahuan dipandang berkembang jika didukung oleh informasi baru. Atau, dengan kata lain, jika terjadi akumulasi informasi.

Begitulah pengembangan sains dalam perspektif positivistik dan kosekuensinya dalam dunia pendidikan. Sementara dalam pandangan Popper, pengembangan sains model positivistik, bukan saja mengandung kelemahan, tetapi bahkan jauh untuk disebut ilmiah. Karena kenyataaanya, membuktikan teori bukanlah pekerjaan yang membutuhkan kecakapan ilmiah tertentu. Untuk itu Popper menawarkan proses pengembangan sains dengan melakukan upaya serius untuk membuktikan salah (falsifikasi). Jika suatu proposisi umpamanya menyatakan "semua angsa berwarna putih", maka proses ilmiah yang dilakukan adalah berusaha semaksimal mungkin untuk menggurkannya, misalnya dengan menemukan angsa bewarna lain atau dengan eksperimen kawin silang atau bisa jadi dengan sistem kloning.

Sebagai konsekuensi dari pandangannya bahwa teori itu pada dasarnya adalah hipotesa yang testable dan falsifiable, Popper melihat bahwa sains baru dikatakan berkembang jika 
suatu teori gugur, tidak bertahan oleh proses falsifikasi, sehingga digantikan oleh teori yang lebih kuat. Maka begitulah, di tangan Popper, teori itu dapat tumbuh, dapat tambah kokoh, bahkan dapat tumbang. Di sini Popper, menempatkan kritik dan penyangkalan (refutability) sebagai bagian terpenting dari tradisi ilmiah yang mesti terbangun. Maka jika dikaitkan dengan proses pendidikan, maka pendidikan bukanlah merupakan proses menambah pengetahuan atau informasi, tetapi upaya tiada henti untuk menyibak ketidaktahuan atau upaya sungguh-sungguh untuk mempersempit ketidaktahuan manusia. Maka belajar bukanlah aktivitas menangkap dan mengoleksi informasi sebanyak-banyaknya secara pasif, tetapi merupakan usaha aktif untuk memecahkan persoalan dan teka-teki kehidupan dengan pendekatan trial and error. Secara lebih sempit, kegiatan belajar dan pembelajaran adalah proses tiada henti untuk menguji setiap apa yang diketahui dengan mengungkap hal-hal baru atau faktafakta baru, sekali lagi, dengan penuh kesungguhan. Intinya, membuat bagaimana seseorang mengalami kenyataan-kenyataan yang berbeda dari harapan-harapan, teori-teori, atau konsepkonsep yang sudah dan sedang dihayatinya. Pengalaman atas kenyataan yang berbeda dari harapan dan teori adalah awal yang baik dalam proses belajar dengan trial and error menuju sebuah pengembangan dan kemajuan pengetahuan. Trial adalah usaha untuk mengoreksi harapan-harapan kita sehingga konsisten dengan kenyataan yang asing dan mungkin juga bertentangan dengan harapan-harapan yang dimiliki. Error adalah kegagalan dalam menjelaskan pengalaman-pengalaman yang bertentangan dengan harapan itu.

Pengembangan sains yang bertumpu pada teori, seperti pembuktian teori Vienna Circle dan penyangkalan teori Popper, membuat perkembangan sains berlangsung linier, homogen, dan rasional. Model seperti ini mendapat kritikan dari Kuhn sebagai tidak berkembang. Dalam analisisnya atas sejarah perkembangan sains, Kuhn menunjukkan bahwa perkembangan sains tidak 
berlangsung linier, homogen, dan rasional seperti itu. Kuhn melihat, sains berkembang melalui revolusi ilmiah dengan membongkar paradigma lama dan menggantinya dengan yang baru. Apa yang dipandang benar dalam paradigma lama akan mengalami krisis sampai ditegakkan suatu paradigma baru dengan kebenaran-kebenaran baru di dalamnya. ${ }^{23}$ Yang sentral di sini adalah pandangan bahwa perubahan paradigma dalam sejarah sains bukan masuk dalam wilayah logis hukum-hukum alam, melainkan terjadi seperti proses "metanoia" (pertobatan) dalam agama. Ini membuat teori-teori dalam paradigma yang satu tak dapat dibandingkan dengan teori-teori dalam paradigma yang lain. $^{24}$

Lebih radikal daripada Popper, Kuhn berhasil menunjukkan bahwa sains memiliki kesamaan dengan dunia politik sehingga kebenaran ilmiah dapat berubah secara revolusioner, bukan evolusi atau akumulatif sebagaimana anggapan sebelumnya. Perkembangan ilmu itu tidak disebabkan oleh dikuatkan dan dibatalkannya suatu teori, tetapi lebih disebabkan oleh adanya pergeseran paradigma. Paradigma pada dasarnya adalah hasil kontruksi sosial para ilmuwan (kominitas ilmiah), yang merupakan seperangkat keyakinan meraka sebagai cara pandang terhadap dunia dan contoh-contoh prestasi atau praktek ilmiah konkrit.

Berbeda dengan teori yang perkembangannya dapat menjadi semakin kokoh atau malah tumbang digantikan oleh teori yang lebih kuat, pergeseran paradigma (shifting paradigm) yang menyebabkan terjadinya revolusi ilmiah berlangsung melalui beberapa tahapan, pertama, tahap ilmu normal (normal science), di mana paradigma ilmiah membimbing dan

\footnotetext{
${ }^{23}$ Thomas S.Kuhn, The Structure of Scientific Revolution (Chicago: The University of Chicago Press, 1970).

${ }^{24}$ Lebih jauh baca Gurry Gutting (Ed.), Paradigms and Revolutions: Appraisals and Applications of Thomas Kuhn's Philosophy of Science (Notre Dame: University of Norte Dame Press, 1980).
} 
mengarahkan aktivitas ilmiah. Di sini para ilmuwan berkesempatan menjabarkan dan mengembangkan paradigma sebagai model ilmiah yang digelutinya secara rinci dan mendalam. Bersamaan dengan itu, para ilmuwan juga berusaha semaksimal mungkin untuk mempertahankan segenap teori yang diakuinya sebagai kebenaran dari seranga kritik, refutasi dan falsifikasi. Kedua adalah tahap anomali (keganjilan). Pada tahap ini para ilmuwan menjumpai berbagai fenomena yang tidak dapat diterangkan dengan paradigma yang digunakan sebagai bimbingan atau arahan aktivitas ilmiahnya. Dalam tahap ini para ilmuwan menunjukkan sikap kritis terhadap paradigma yang selama ini diakuinya. Anomali adalah suatu keadaan yang memperlihatkan adanya ketidakcocokan antara kenyataan (fenomena) dengan paradigma yang dipakai.

Tahap ketiga adalah tahap krisis. Menumpuknya anomali, sebagai akibat dari sikap kritis komunitas ilmiah, menimbulkan krisis kepercayaan terhadap paradigma. Paradigma mulai diperiksa dan dipertanyakan. Para ilmuwan mulai keluar dari jalur ilmu normal. Tahap keempat, para ilmuwan mulai mengembangkan suatu paradigma tandingan yang dipandang bisa memecahkan masalah dan membimbing aktivitas ilmiah berikutnya. Proses peralihan dari paradigma lama ke paradigma baru inilah yang dinamakan revolusi ilmiah (scientific revolution).

Dalam dunia pendidikan, pandangan Kuhn ini terkait paradigma, pola pikir atau bahkan pandangan dunia (worldview) yang dikembangkan seseorang atau dunia pendidikan pada umumnya. Maka, dengan bertambahnya informasi sebagaimana positivistik atau dengan berkurangnya ketidaktahuan sebagaimana falsifikasi Popperian belum menjamin ilmu pengetahuan seseorang bertambah. Ilmu atau pengetahuan akan dikatakan bertambah atau berkembang jika terjadi perubahan pada paradigma atau worldviewnya. Artinya, ditingalkannya paradigma lama menuju paradigma baru. 
Pandangan Kuhn, terutama pada tahap sains normal ini jelas akan menyulitkan proses faksifikasi dalam pengembangan sains, karena pasti akan mendapat penolakan oleh para ilmuwan, atau paling tidak kondisi itu akan dipertahankan sekuat tenaga. Artinya, jika falsifikasi dilanjutkan berarti sains normal itu sebenarnya tak akan pernah terwujud, dan sebaliknya jika sains nomal itu ada, maka proses falsifiksi itu juga hanyalah akal-akalan saja. Perdebatan antara faksifikasi Popperian dan revolusi ilmiah Kuhnian ini yang kemudian menarik Imre Lakatos untuk menawarkan gagasan "Metodology of Scientific Research Programmes" sebagai kritik sekaligus pengembangan terhadap kedua pemikiran itu. Berbeda dengan Kuhn yang memberikan kemungkinan terjadinya revolusi sebagai sesuatu yang luar biasa dalam perkembangan sains, Lakatos justru tidak melihat perkembangan sains terjadi dengan revolusi. Menurut Lakatos, perkembangan sains dapat terjadi melalui kontinuitas. Bahkan jika sebuah program riset terfalsifikasi, program tersebut tidak lantas terpuruk, tetapi ia masih memiliki kekuatan untuk bangkit kembali guna meraih kemapanan. ${ }^{25}$

Tawaran Lakatos "Metodologi Program Riset" dimaksudkan sebagai struktur metodologis yang memberikan bimbingan untuk riset masa depan dengan cara positif dan negatif. Menurut Lakatos, ada tiga elemen yang harus ada dalam suatu program riset, yaitu: pertama, "inti pokok" (hard-core), dalam hal ini "asumsi dasar" yang menjadi ciri dari program riset ilmiah yang melandasinya, yang tidak dapat ditolak atau dimodifikasi. "inti pokok" ini dilindungi dari ancaman falsifikasi. ${ }^{26}$ Dalam aturan metodologis program riset, hard-core ini disebut sebagai heuristik negatif, yaitu "inti pokok" yang menjadi dasar bagi elemen yang lain; kedua, "lingkaran pelindung" (protective-belt)

\footnotetext{
${ }^{25}$ Imre Lakatos dan Alan Mosgrave (Eds.), Criticism and the Growth of Knowledge (Cambridge: Cambridge University Press, 1974), h. 92-93.

${ }^{26}$ Imre Lakatos, "Falsification and the Methodology of Scientific Research Programmes”, dalam ibid., h. 135.
} 
yang terdiri dari hipotesa-hipotesa pendukung (auxiliary hypotheses) dalam kondisi-kondisi awal. Dalam mengartikulasi hipotesa pendukung, lingkaran pelindung ini harus menahan berbagai serangan, pengujian dan memperoleh penyesuaian, bahkan perubahan dan pergantian, demi mempertahankan hardcore. Dalam aturan metodologis program riset, protective-belt ini disebut "heuristik positif". Heuristik positif terdiri dari seperangkat saran atau isyarat tentang bagaimana mengembangkan varian-varian yang kompleks; bagaimana memodifikasi dan meningkatkan lingkaran pelindung yang fleksibel; dan ketiga, serangkaian teori (a series theory), yaitu keterkaitan teori di mana teori yang berikutnya merupakan akibat dari klausul bantu yang ditambahkan dari teori sebelumnya.

Tawaran Lakatos ini tampaknya tidak hanya bisa mendudukkan posisi konsepsi vienna circle, Popper, dan Kuhn, tetapi bahkan ia bisa mendamaikan ketiganya dalam suatu program riset (atau dalam hal ini, program pengembangan ilmu). Sehingga setiap aktivitas keilmuan selalu memiliki tiga elemen penting yang menjadi basis tumbuh-kembannya, yaitu "teori" [yang bisa dikembangkan dan bisa juga digugurkan], "paradigma" sebagai dasar dari bangunan teori, dan "asumsi dasar" yang pada dasarnya merupakan basis teologis-metafisis dari aktivitas keilmuan.

\section{HAKIKAT PENDIDIKAN DALAM PANDANGAN FILSAFAT ILMU}

Berdasarkan uraian di atas, ternyata proses dan hasil keilmuan pada jenis ilmu apapun, ternyata sangat ditentukan oleh landasan filosofis yang mendasarinya, yang memang berfungsi memberikan kerangka, mengarahkan, menentukan corak dari keilmuan yang dihasilkannya. Landasan filosofis dimaksud adalah kerangka teori (theoretical framework), paradigma keilmuan dan, asumsi dasar. Ketiga hal inilah yang lazim disebut dengan filsafat ilmu atau filsafat keilmuan, dalam 
arti, basis filosofis yang mendasari bangunan keilmuan dan aktifitas ilmiah pada umumnya.

Kaitannya dengan pendidi-kan, bisa dilihat dari diagram sederhana di bawah bahwa proses dan jalannya pendidikan pada wilayah praksis merupakan aplikasi dari teori pendidikan yang telah melalui kajian ilmiah secara mendalam. Dengan kata lain,

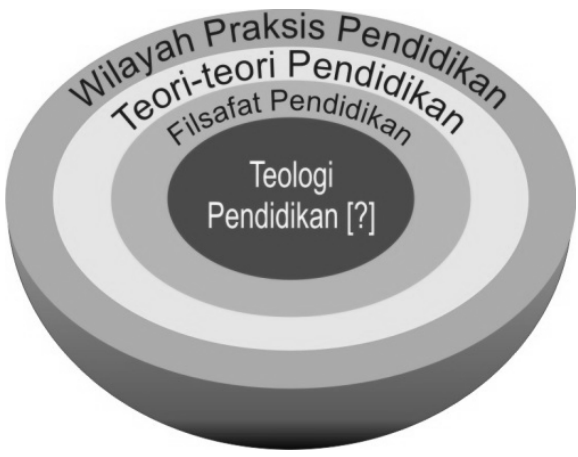
apapun proses pendidikan pada wilayah praksis ini pasti berbasis teori tertentu, atau paling tidak, bisa dikonstruksi bangunan teorinya.

Sementara Filsafat Pendidikan secara sederhana bisa dimengerti sebagai basis filosofis yang mendasari praksis dan teori pendidikan. Beragamnya teori pendidikan harus dimaknai sebagai beragamnya pilihan ilmiah. Maka penetapan teori (sebagai software) mesti mempertimbangkan competabilitynya dengan situasi dan kondisi (tersedianya hardware) pendidikan yang ada.

Setiap teori memiliki kerangka kerja (theoretical framework) yang lazim disebut metodologi, sehingga setiap teori berkonsekuensi metodologis tertentu. Berbeda teori akan berbeda metodologinya. Dalam bangunan keilmuan, metodologi merupakan aspek logis dan objektif yang memungkinkan temuantemuan ilmiah dapat diterima (atau ditolak) secara rasional dan objektif. Itulah sebabnya, metodologi sering dimaknai sebagai logic of discovery (logika penemuan). Dengan begitu, metodologi berbeda dengan metode yang maknanya adalah process and prosedure. Bedanya, yang disebut pertama bersifat filosofis dan strategis, sedang yang disebut belakangan bersifat teknis. Dalam kegiatan keilmuan dan termasuk pendidikan, sekalipun keduanya tak dapat dipisahkan, namun tetap memiliki wilayahnya sendiri- 
sendiri. Dari sini kemudian bisa dimengerti adagium pendidikan yang sudah menjadi populer: al-thariqah ahamm min al-maddah (metodologi lebih penting dari pada materi). Jika dalam Ilmu Pendidikan ditemukan beberapa teori, itu berarti tersedia beberapa tawaran metodologi sebagai kerangka dalam proses pendidikan. Hal ini, harus dipahami bahwa masing-masing teori, tengah 'berdiskusi' tentang persoalan metodologi. Karena setiap teori memang menyediakan logic of discovery sesuai dengan kerangka logikanya masing-masing. Sehinga setiap teori berkonsekuensi metodologis tertentu.

Sementara paradigma ilmiah adalah pola pikir kolektif dari scientific community yang lahir dan menjadi rasional, logis dan baku melalui proses sejarah yang panjang. Posisinya menjadi basis tumbuhkembangnya segala aktivitas keilmuan. Dalam dunia pendidikan, paradigma merupakan basis filosofis dan sosiohistoris sekaligus. Sehingga posisi eksistensi guru, dosen, mursyid, penyelenggara, yayasan dan organisasi afiliasi, dst tidak diabaikan begitu saja, bahkan diakui sebagian bagian tak terpisahkan dalam bangunan keilmuan dan proses pendidikan. Di sini kemudian bisa dipahami pernyataan bahwa sekalipun metodologi penting, tapi bukanlah segala-galanya, karena bagaimanapun al-mudarris ahamm min al-thariqah (guru [dan penyelenggara] lebih penting dari metodologi)

Sedangkan asumsi dasar adalah sisi terdalam dari bangunan keilmuan. Sifatnya lebih halus dari paradigma dan teori. Dalam bangunan keilmuan, asumsi dasar dimaksudkan sebagai basis teologis-metafisis, karena memang terkait dengan keyakinan atau bahkan keimanan ilmuwan. Dalam perspektif "filsafat ilmu" klasik, posisi basis teologis-metafisis ini bisa diidentikkan dengan "premis mayor" sebagaimana dalam logika tradisional Aristoteles, atau berkedudukan sebagai "idea transendental" sebagaimana epistemologi Immanuel Kant. "Idea transendental” ini merupakan 
cita yang menguasai segenap pemikiran. ${ }^{27}$ Idea ini sifatnya semacam "indikasi-indikasi kabur", yang berupa petunjukpetunjuk yang membimbing "akal murni" dan "akal praktis. Seperti juga kata "barat" dan "timur" yang merupakan petunjukpetunjuk: "timur" an sich tidak pernah bisa diamati. Kaitannya dengan pengembangan ilmu, idea transendental itu merupakan "postulat" atau "aksioma"28 yang berperan sebagai asumsi, orientasi dan arah bagi kerja ilmiah. Oleh karena itu, keberadaannya di luar jangkauan pembuktian teoretis-empiris. ${ }^{29}$

Sementara dalam perspektif Filsafat Ilmu kontemporer, asumsi dasar itu justru menjadi "inti" (hard core) dalam segala aktivitas ilmiah sebagaimana ditawarkan Lakatos. Hard core bersifat negative heuristic sehingga tidak bisa dikritik atau disalahkan. Posisinya sangat kuat karena dijamin oleh protective belt (lingkaran pelindung). Di luarnya masih terbangun sejumlah

\footnotetext{
${ }^{27}$ Sifat idea ini, menurut Kant: inteligible, clear, and decisive..... the transcendental ideas therefore express the peculiar application of reason as a principle of systematic unity in the use of understanding. Lihat Immanuel Kant, Prolegomena to Any Future Metaphysics, terj. The Paul Carus, revisi oleh James W. Ellington (Indianapolish/Cambridge: Hackett Publishing Company, 1977), h. 89-90.

${ }^{28}$ F. Budi Hardiman, Filsafat Modern, dari Machiavelli sampai Nietzsche (Jakarta: PT Gramedia Pustaka Utama, 2004), h. 143.

${ }^{29}$ Menurut Kant, ada tiga Idea transendental. Pertama Idea psikis (jiwa) yaitu merupakan gagasan mutlak yang mendasari segala gejala batiniah. Kedua, gagasan yang menyatukan segala gejala lahiriah, yakni Idea kosmologis (dunia). Dan akhirnya, gagasan yang mendasari segala gejala, baik yang lahiriah maupun yang batiniah, yaitu yang terdapat dalam suatu pribadi mutlak, yakni Tuhan sebagai Idea Teologis. Kendati Kant menerima ketiga Idea itu, ia berpendapat bahwa ide-ide itu tidak bisa diketahui lewat pengalaman. Lihat S.P. Lili Tjahyadi, Hukum Moral, Ajaran Immanuel Kant tentang Etika dan Imperatif Kategoris (Yogyakarta: Kanisius, 1991), h. 38-39; Dengan Kritik-nya ini, Kant sekaligus menunjukkan kekeliruan argumen ontologis, kosmologis dan teleologis dalam metafisika tradisional yang dikatakan dapat membuktikan adanya Tuhan. Menurut Kant, argumen metafisika tradisional itu telah jatuh ke dalam paralogisme (penalaran sesat). Bagaimana kekhasan argumen-argumen tersebut dan bagaimana kritik Kant, lihat Amsal Bakhtiar, Filsafat Agama (Jakarta: Logos Wacana Ilmu, 1997), h. 169-188.
} 
teori yang secara koheren saling mendukung dan berkembang sesuai dengan perkembangan hipotesa (auxillary hypotheses). Teori-teori ini bersifat positif heuristic yang kemungkinan bisa berkembang dan disalahkan. Hard core, negative heuristic dan protective belt dalam konsepsi Lakatos inilah yang memungkinkan pendidikan yang berbasis agama seperti pendidikan Islam menjadi bangunan keilmuan yang ilmiah. Lebih dari itu, menempatkan kata Islam di belakang kata pendidikan kemudian terkesan menjadi sangat wajar dan tidak aneh.

Sudah tentu asumsi teologis-metafisis yang dimaksud di sini terkait dengan konsep asasi, seperti hakikat kehidupan, dunia, ilmu, dan bahkan keagamaan dan ketuhanan. Beberapa hal ini bisa disebut fundamental elements of the worldview. Maka Islamic worldview sebagaimana dimaksudkan oleh Alparslan dan Al-Attas, dalam perspektif Filsafat Ilmu, tidak lain merupakan basis teologis-metafisis atau hard core atau premis mayor atau ide transendental dalam keilmuan pendidikan Islam. Inilah yang membedakan pendidikan yang berbasis agama Islam dengan pendidikan yang berbasis agama lain, atau dengan pendidikan yang tidak berbasis agama, jika ada. Dalam diskursus pemikiran Islam kontemporer, asumsi teologis-metafisis ini bisa diidentikkan dengan problem al-tsawabit (yang mapan) sementara paradigma dan teori bisa diidentikkan dalam wilayah al-mutahawwil (yang berubah), sekalipun ada perbedaan dalam perubahannya. ${ }^{30}$

Dengan begitu, ambiguitas terhadap istilah pendidikan Islam telah mendapat jawabannya dari sudut pandang filsafat ilmu. Sekedar mempertegas lagi, bahwa dalam perpektif filsafat ilmu kontemporer, model pendidikan mestinya memberi

\footnotetext{
${ }^{30}$ Adonis, Al-Śābit wa al-Mutahawwil: Bahs fị al-Ibdā' wa al-Ittibā' 'inda al-'Arab (Yang Mapan-Statis dan Yang Berubah-Dinamis: Kajian atas kreativitas dan konservativitas menurut bangsa Arab). Buku ini telah diterjemahkan kedalam bahasa Indonesia oleh Khoiron Nahdiyin dengan judul: Arkeologi Sejarah Pemikiran Arab-Islam (Yogyakarta: LkiS, 2007).
} 
penekanan pada tiga elemen filsafat keilmuan sekaligus, yaitu: teori dan metodologi pendidikan, filsafat dan sosiologi pendidikan, dan teologi dan metafisika pendidikan. Tiga elemen filosofis ini jelas membawa dunia pendidikan tampil lebih berkarakter, kokoh, dan tidak pargmatis, karena keyakinan bahkan keimanan Islam sebagai basis teologis-metafisis penyelenggara telah memiliki posisi yang jelas sebagai bagian tak terpisahkan dalam proses pendidikan yang dikembangkannya. Di sini dua adagium pendidikan sebagaimana disebut di atas semakin lengkap dengan terpaterinya adagium ketiga, yaitu ruh almudarris ahamm min al-mudarris nafsah (spirit, prisip hidup, keyakinan dan keimanan guru [penyelenggara] jauh lebih penting dari pada guru itu sendiri).

\section{PENUTUP}

Sampai di sini bisa dikatakan bahwa konsep dan praksis pendidikan ternyata memiliki keterkaitan dengan problem keilmuan. kritisisme atau pembacaan secara lebih kreatif terhadap pemikiran filsafat ilmu sudah tentu akan dapat memperjelas logika pedagogik yang-disadari atau tidakmendasari praksis pendidikan yang sedang kita jalankan. Dalam perspektif filsafat ilmu, bangunan keilmuan pendidikan atau aktivitas praksis pendidikan pada umumnya memang sangat ditentukan oleh ketepatan dalam penggunaan teori dan pada akhirnya juga metodologinya. Ketepatan itu dapat diukur dengan prediksi-prediksi ilmiah yang mungkin dihasilkan, juga dilihat dengan signifikansi dan contability-nya dengan situasi dan kondisi yang ada. Namun demikian, peran subjektif penyelenggara dengan pertimbangan filosofis dan sosiologis tetap tidak diabaikan. Demikian juga sisi keyakinan, keimanan, dan prinsip hidup juga sangat menentukan pemilihan paradigma dan teori pendidikan yang diterapkan. Kekuatannya pada prinsip hidup membuat pendidikan lebih berkarakter. 
Teori dan metodologi pendidikan telah menjadi kajian yang cukup menarik pada bidang ilmu pendidikan. Sementara paradigma pendidikan menjadi pembahasan filosofis yang tidak kalah serunya dalam bidang filsafat pendidikan, Sosiologi Pendidikan, dan sejarah pendidikan. Namun harus diakui, problem keyakinan, prinsip hidup, dan keimanan dalam kaitannya dengan pendidikan belum banyak dibahas, sehingga masih sangat terbuka untuk dikaji. Problem inilah secara khusus, penulis sebut sebagai wilayah teologi pendidikan, sebagai satu bidang yang mengkaji nilai, spirit, dan aspek keberagamaan sebagai bagian tak terpisahkan dalam dunia pendidikan, sebagaimana ditunjukkan pada diagram di atas.

\section{DAFTAR PUSTAKA}

Adonis, Al-Sāabit wa al-Mutahawwil: Baḥs fī al-Ibdā' wa al-Ittibā' 'inda al-'Arab (Arkeologi Sejarah Pemikiran Arab-Islam), Yogyakarta: LkiS, 2007.

Arif, Syamsuddin, 'Transmigrasi Ilmu': Dari Dunia Islam ke Eropa, dalam Tsaqafah, Jurnal Peradaban Islam, Vol. 6, No. 2.

Asyqar-al, Muhammad Sulayman, al-Mustasfā, Beirut: Mu'assasah alRisālah, 1997.

Bakar, Osman, Hierarki Ilmu Membangun Rangka Pikir Islamisasi Ilmu, Bandung: Mizan, 1997.

Bakhtiar, Amsal, Filsafat Agama, Jakarta: Logos Wacana Ilmu, 1997.

Bertens, Kees, Filsafat Barat Abad XX: Inggris-Jerman Jakarta: Gramedia, 1983.

Bucaille, Maurice, Bibel Qur'an dan Sains, terj. A. Rasyidi, Jakarta: Bulan Bintang, 1992.

Corbin, Henry, History of Islamic Philosophy, London and New York: Kegan Paul International, 1962.

Foucault, Michel, The Order of Think: An Archeology of Human Sciences, New York: Vintage Books, 1994.

Ghazali-al, al-Mustașfā min 'Ilm al-Ușūl, Kairo: Maktabah al-Amiriyyah, 1904. 
Gutting, Gurry (Ed.), Paradigms and Revolutions: Appraisals and Applications of Thomas Kuhns Philosophy of Science, Notre Dame: University of Norte Dame Press, 1980.

Hardiman, F. Budi, Filsafat Modern, dari Machiavelli sampai Nietzsche, Jakarta: PT Gramedia Pustaka Utama, 2004.

Ibn Rusyd, Fașl al-Maqāl fĩ Taqrīr ma Bain al-Syarīah wa al-Hikmah min al-Ittiṣāl, tahqīq Abid al-Jabiri, Libanon: Markaz Dirāsah alWahdah al-'Arabiyah, 2007.

Jabiri, Abed al-, Bunyah al-'Aql al-'Arabī, cet. ke-8; Beirut: Markaz Dirāsah al-Waḥdah al-'Arabiyyah, 2004.

Jabiri, Abed al-, Takwīn al-'Aql al-'Arabī, cet. ke-8; Beirut: Markaz Dirāsah al-Wah̀dah al-'Arabiyyah, 2002.

Kant, Immanuel, Critique of Pure Reason, Translated by JMD. Meiklejohn, New York: Prometheus Books, 1990.

Kant, Immanuel, Prolegomena to Any Future Metaphysics, terj. The Paul Carus, revisi oleh James W. Ellington, Indianapolish/Cambridge: Hackett Publishing Company, 1977.

Kuhn, Thomas S., The Structure of Scientific Revolution, Chicago: The University of Chicago Press, 1970.

Lakatos, Imre dan Alan Mosgrave (eds.), Criticism and the Growth of Knowledge, Cambridge: Cambridge University Press, 1974.

Lakatos, Imre, "Falsification and the Methodology of Scientific Research Programmes", dalam Imre Lakatos dan Alan Musgrave (eds.), Criticism and the Growth of Knowledge, Cambridge: Cambridge University Press, 1974.

MacIntyre, A, "Popper, Karl Raimund," dalam The Encyclopedia of Philosophy, Edited by Paul Edwards, New York: The Macmillan Company and The Free Press, 1967.

Madjid, Nurcholish, Khazanah Intelektual Nurcholish Islam, Jakarta: Bulan Bintang, 1984.

Muslih, Mohammad, Filsafat Ilmu; Kajian atas Asumsi Dasar, Paradigma, dan Teori Dasar Ilmu Pengetahuan, Yogyakarta: Belukar Budaya, 2005. 
Popper, Karl R., Logic of Scientific Discovery, New York: Harper and Row, Harper Torchbooks, 1965.

Sidik, Abdullah, Islam dan Filsafat, Jakarta: Triputra Masa, 1984.

Taryadi, Alfons, Epistemologi Pemecahan Masalah Menurut Karl Popper Jakarta: PT Gramedia Pustaka Utama, 1991.

Tjahyadi, S.P. Lili, Hukum Moral, Ajaran Immanuel Kant tentang Etika dan Imperatif Kategoris, Yogyakarta: Kanisius, 1991.

Verhaak, "Plato: Menggapai Dunia Idea", dalam Sutrisno F.X Mudji dan F. Budi Hardiman, Para Filsuf Penentu Gerak Zaman, Yogyakarta: Kanisius, 1994.

Williams, Bernard, "Rene Descartes", dalam Paul Edwards (ed.), The Encylopaedia of Philosophy, Vol. I dan 2, 1992. 